seeking to protect the merchant ship, is conducting itself like a strong man who in a lonely place sees a violent assault on women and children without intervening, cannot be agreed to. Such assault appears on its face felonious; that of the warship appears on its face to be the lawful exercise of a belligerent right. However painful to witness it may be, the neutral bystander has no right to intervene any more than to interfere with the lawful, though distressing, exercise of force by a police or sheriff-officer.

In a fierce, destructive war, involving every first-class Power except the United States, when the most well-established neutral rights are invaded, minimized and denied, it is submitted that our country is not called on to apologize for failure to assert such shadowy, unestablished, contentious, and it is believed, repudiated claims to jurisdiction over the high seas as these advanced by De Cussy.

The views here expressed have met with the approval of a considerable number of naval officers of high rank and special knowledge, who were consulted, and of various students of international law. Not one of these gentlemen doubted or denied them.

Charles Noble Gregory

\title{
SUBMARINES AND INNOCENT PASSAGE
}

The activity of the German U-boat 53 by its entrance into the harbor of Newport, its short stay there, and its departure for the open sea, followed within a few hours by its destruction of several enemy and neutral merchant vessels outside the three-mile limit, raises important questions concerning the rights and duties of a neutral Power over its territorial waters. The first concerns the doctrine of "innocent passage"; the second, the question of "due diligence"; the third, the extension of territorial jurisdiction in time of war beyond the traditional limit of a marine league.

The doctrine of "innocent passage" is in a way a working compromise between the right of a littoral state to jurisdiction over the marginal sea and the right of maritime powers to make use of the high seas as a universal highway of commerce and navigation. The purpose of such territorial jurisdiction is both strategic and economic. Its extent, despite the extravagant claims of the sixteenth and seventeenth centuries, came to be limited theoretically by the power of the 
littoral state exerted from the shore. As was said by Sir Thomas Barclay in his report at the meeting of the Institute of International Law of 1894, held at Paris:

Do not let us forget that the distance of a cannon-shot from the coast is a fiction and has never been anything but a fiction. It is the invention of Bynkershoek, who found in it a formula by which the various and more or less exaggerated claims might be reduced to a common and reasonable limit. ${ }^{1}$

"The smallest distance, I believe," wrote Jefferson to Hammond and Genêt, November $8,1793,{ }^{2}$ "claimed by any nation whatever, is the utmost range of a cannon-ball, usually stated at one sea league."

This marine league, set forth as the minimum of jurisdictional extent, is generally regarded as its maximum, notwithstanding the fact that the development of ordnance has multiplied the range of guns many times since Jefferson wrote. While the doctrine has its basis in strategic protection to the littoral state, experience has demonstrated its necessity for the conservation of national marine resources and, furthermore, that such conservation is not always possible when the jurisdiction of the littoral state ends at the arbitrary distance of three miles. This thesis has been admirably sustained by Professor T. W. Fulton in his learned and exhaustive treatise entitled The Sovereignty of the Sea. ${ }^{3}$ In this respect international practice has acquiesced in certain extensions of the three-mile limit. The strategic practice is, however, upon a different if not more ancient footing. While logically the extent of the marginal sea should vary with the increase of the power of ordnance, there is no likelihood that the established observations of more than a century would permit any general extension, notwithstanding the resolution of the Institute of International Law in 1894, a part of which was as follows:

The Institute, considering that there is no basis for limiting in a single zone the distance necessary for the exercise of sovereignty and for the protection of coast fisheries and that which is necessary in order to guarantee the neutrality of non-belligerents in time of war,

1 Annuaire de l'Institut de Droit International, XIII, 127.

2 Moore, International Law Digest, I, 702.

3 The Sovereignty of the Sea: An Historical Account of the Claims of England to the Dominion of the British Seas, and of the Evolution of the Territorial Waters: with special reference to the Rights of Fishing and the Naval Salute. By Thomas Wemyss Fulton, Lecturer on the Scientific Study of Fishery Problems, the University of Aberdeen. William Blackwood and Sons, Edinburgh and London, 1911. 
That the distance usually adopted of three miles from low-water mark has been recognized as insufficient for the protection of shore fisheries,

That this distance no longer corresponds to the actual range of cannon from the shore, has adopted the following dispositions:

Article I. The state has the right of sovereignty over a sea zone which bathes the coast, subject to the right of innocent passage reserved in Article V. This zone carries the name of territorial sea.

Article II. The territorial sea extends to six marine miles (sixty to a degree of latitude) from low-water mark over the whole extent of the coast. ${ }^{1}$

The littoral state must generally content itself with making its jurisdiction effective over the marginal seas within the traditional three-mile limit, and it thus becomes necessary to scrutinize all acts proceeding from the right of innocent passage from the standpoint of the security of the state. This security is of two kinds: first, the direct protection of the coast-line, ports, and waters from violation or evasion of the municipal laws of the littoral state regarding customs, quarantine, and the safety of navigation, in peace as well as in war; and second, the indirect security which demands the performance of the positive duties of neutrality.

So far as submarine navigation is concerned, these questions are practically limited to times of war, for while the submarine might, like the aeroplane, be a tolerably effective smuggling instrumentality in time of peace, no one conceives that the peaceful oceanic navigation of the future, any more than in the past, will be other than surface navigation. It is only in time of war, therefore, that the question is apt to become one of prime importance. The dramatic exploits of the Deutschland, for example, have little significance for the development of navigation in time of peace, and the notoriety of them at the present time is not so much for the purpose of demonstrating the possibility of the submarine as a merchandise carrier, as to give to that type of vessel a legal status as a possible merchantman, adding another element of difficulty to the whole U-boat problem and thereby making confusion worse confounded. If the submarine has such a status, and neutral goods are shipped thereon, all the dominant questions of visitation and search and of the capture of merchantmen are raised. It is not the vessel's submarine qualities which give it a merchantman status, but its compliance with the test of a merchant-

1 Annuaire de l'Institut de Droit International, XIII, 329; Resolutions of the Institute of International Law, English translation, New York: Oxford University Press (American Branch). 1916. p. 113. 
man and its ability to conform to the navigation laws of the country . whose waters it seeks to enter. These laws are universally framed upon the theory of surface navigation. If, therefore, a submarine, assuming a merchantman status, enters the territorial waters of a foreign state in time of peace or war, that state may properly require of it that it remain upon the surface while and as long as it is in such waters, so that it may conform to the accepted standards of safety to navigation. The littoral state has the right and the duty to protect its territorial waters from dangerous usages - and any navigation below the surface of the water is, at least at the present time, such a usage, as was shown by the refusal of the Deutschland to take on a pilot and its collision with a tug off New London with consequent loss of life.

The United States has minute regulations for the navigation of its territorial waters. A motor-boat of sixteen-foot length must be provided with starboard and port lights and be otherwise equipped in the interest of safety. That a state would be within its rights in requiring surface-navigation of its territorial waters in time of peace is unquestioned. Obedience to such requirements would be the duty of all vessels, national or foreign, public as well as private. As to this the Institute of International Law, at the same Paris meeting, laid down the following proposition:

Ships traversing territorial waters must conform to special regulations of the littoral state in the interest and for the security of navigation and maritime police.

More important, however, for the present purpose is the question of the indirect security of a littoral state during war because of the positive duties of neutrality. "Innocent passage" of belligerent cruisers through neutral waters is not a fancy nor an abstraction. The gist of the idea is that any activity having immediate strategic value by a belligerent warship in territorial waters compromises the neutrality of the Jittoral state. This is the underlying principle which controls all the questions involving entry into and departure from neutral ports. The "line of respect" does not rest upon the same basis as does the line of jurisdiction over the territorial sea for the purposes of commerce, navigation, and fisheries. While it has its origin in the right of the littoral state to be secure from belligerent acts directly endangering its coasts and coastwise shipping, with the development of the doctrine of positive neutral duties it has come to 
include an area within which no belligerent acts of strategic purpose are to occur and within which the neutral state is bound to see that none takes place.

It is in this connection that the doctrine of innocent passage requires consideration. A further resolution adopted by the Institute of International Law in 1895 stated:

All vessels without distinction have the right of innocent passage through the territorial sea, reserving to belligerents the right to regulate, and, for the purposes of defense, to bar the passage of all vessels from such waters, and reserving to neutrals the right to regulate the passage within such waters of the warships of all nationalities.

In other words, it is for the neutral littoral state to decide as to what constitutes innocent passage in time of war with reference to belligerent warships. It will be noted that the Institute decided that such regulations might be made either at the outbreak of war, in the declaration of neutrality, or during the progress of the war by special regulations. Attention is called to this distinction to meet the objection sometimes raised that any change in the policy of a neutral toward belligerents during war is a violation of neutral duties.

To be innocent, the passage is not merely to be innocuous so far as the littoral's immediate property interests, or the property interests of its nationals, are concerned, but inoffensive in the sense that it does not compromise the positive neutrality of the littoral state. As a neutral state is bound not to suffer or permit one belligerent to make use of its ports or waters as the base of naval operations against another belligerent, its positive duties become more onerous and exacting with the development of every new instrument of maritime warfare. A measure of precaution sufficient to prevent sailing vessels from making use of territorial waters as a base was not a sufficient standard for the treatment by a neutral of belligerent steam ironclads. What is enough to prevent surface operating steam vessels from making territorial waters a base may not be a sufficient standard when submarines are involved. In each case the neutral state is bound to reëxamine the question of innocent passage and to regulate the use of its waters accordingly.

New neutral duties growing out of submarine navigation were implied by the notes of the Allies to the neutral Powers in August last. A memorandum from the French Embassy to the Department of State, dated August 29, 1916, warned neutrals against allowing 
belligerent submarines, regardless of their use (i.e., either "merchant" or war submarines), to avail themselves of neutral waters roadsteads and harbors:

In the case of submarines the application of the principles of international law offers features that are as peculiar as they are novel, by reason, on the one hand, of the facility possessed by such craft to navigate and sojourn in the seas while submerged and thus escape any supervision or surveillance, and, on the other hand, of the impossibility to identify them and determine their national character, whether neutral or belligerent, combatant or innocent, and to put out of consideration the power to do injury that is inherent in their very nature.

It may be said, lastly, that any submarine war vessel far away from its base, having at its disposal a place where it can rest and replenish its supplies, is afforded, by mere rest obtained, so many additional facilities that the advantages it derives therefrom turn that place into a veritable basis of naval operations.

Therefore the Allied Governments held that all submarines should be excluded from neutral waters or, having entered them, they should be interned.

The United States declined to accede to any such sweeping general doctrine, but stated that

So far as the treatment of either war or merchant submarines in American waters is concerned, the Government of the United States reserves its liberty of action in all respects and will treat such vessels as, in its opinion, becomes the action of a Power which may be said to have taken the first steps toward establishing the principles of neutrality and which for over a century has maintained those principles in the traditional spirit and with the high sense of impartiality in which they were conceived.

Since then the German U-boat 53 has followed the Deutschland to American waters with results known to all the world.

Norway took an essentially different position in answer to the memorandum of the Allies. It declared that it had the right to prohibit submarines designed for war purposes and belonging to belligerents from passing through Norwegian territorial waters (i.e. to a distance of four miles) or sojourning in them, but that it did not conceive it to be its duty as a neutral absolutely to interdict such passage and sojourn. The right to regulate such passage being included in the larger right, the Norwegian Government by a royal decree, dated October 13 last, "forbade belligerent submarines to traverse Norwegian waters except in case of emergency, when they must remain upon the surface and fly the national flag." Merchant submarines are by the same decree to be allowed in Norwegian waters 
only in a surface position in full daylight and when flying the national colors. Whether or not Norway can enforce this decree is problematical, not because of the questions of law involved, but because the belligerent most affected may be able to use force against Norway, a relatively weak Power.

So far the exploit of the $\mathrm{U}-53$ is a unique incident. It is to be hoped that it will remain so. Its repetition might go far toward compromising the neutrality of the United States. As a single incident, it forcibly emphasizes the wisdom of the resolution adopted by the Institute of International Law at the same session Article IV:

In case of war the neutral littoral state has the right by the declaration of neutrality or by special notification to fix its neutral zone beyond six miles to the range of a cannon-shot from its shores.

Absolutely to interdict under-surface navigation in territorial waters by all foreign submarines in war or peace, and to insist upon "innocent passage" that is really innocent in coastal waters as far from the coast as the range of the most modern ordnance, would go far toward preventing the waters adjacent to the neutral being made a base of belligerent maritime operations. It would render difficult submarine operations begun by submerging in coastal waters and consummated in the open sea dum fervet opus.

J. S. Reeves

\section{SAFE CONDUCT FOR ENEMY DFPLOMATIC AGENTS}

ON September 8, 1915, the Secretary of State requested the recall of the Austrian Ambassador because of his proposed plans to instigate strikes in American manufacturing plants engaged in the production of munitions of war. The request was complied with, and on October 5, 1915, Dr. Dumba left the United States, the Department of State securing for him a safe-conduct. Count Adam Tarnowski von Tarnow, after an interval of some thirteen months, has been appointed Austrian Ambassador to the United States, and just as his predecessor wished a safe-conduct to return to his native land, he was apparently anxious to receive a safe-conduct for himself and his suite from the shores of Europe to Washington. About the middle of November the United States informed Great Britain and France that Count Tarnowski had been appointed Ambassador to the United States and the question of a safe-conduct for the Austrian 